\title{
Impact of Attitude Towards Human Resource Accounting on Performance of Undergraduate Students' Education - Evidence From Private University Students in Kurdistan Region - Iraq
}

\author{
Tamminana Kamaraju, Krishna Surarchith Navulur, Yusra Farooq Baqal
}

\begin{abstract}
The current research was undertaken to find the impact of attitude towards Human Resource Accounting on performance of undergraduate student's education. The research was carried out as a pilot study on accounting department's students who are pursuing their $3^{\text {rd }}$ year and final year of their under graduation in a private university which is located in Kurdistan Region Iraq. The total number of students in accounting department was 125 where 59 students responded to the questionnaire distributed. Researchers used Delphi technique where respondents are given chance to choose their responses in the first round randomly. All results of each item of the survey were shown to the respondents in the second round and requested to re-confirm their responses and provided freedom to change their responses. Researchers found few differences from first round to the second round of survey with the same respondents. Researchers constructed a basic model to understand the impact of predicted variable and predictor variables. The predictor variable for current research is attitude towards Human Resource Accounting and Predicted variable is performance of undergraduate students' education. The null hypothesis got rejected in the study. The research gap was identified by the researchers as literature was completely focused on reporting, measuring and evaluating the human values but overlooked the attitude part related to human resource accounting. Current research helps the educational institutions to understand the value of human resource accounting and implication of it to achieve high level of productivity among student community.
\end{abstract}

Key Words: Human Resource Accounting, attitude, performance and students

\section{INTRODUCTION}

Accounting for human assets are included in Human In spite of the fact that HRA has significant involvement for external financial reporting, in the economic environment

Revised Manuscript Received on July 25, 2019.

Tamminana Kamaraju,

Department of Commerce \& Management Studies, Dr. B.R. Ambedkar University, Sikakulam, Andhra Pradessh, India

Krishna Surarchith Navulur,

Accounting Department, Tishk International University (Formerly known as Ishik University), Erbil, Iraq, Research Scholar of Dr. B.R. Ambedkar University, India

Email:krishna.navulur@ishik.edu.iq

Yusra Farooq Baqal,

Accounting Department, Tishk International University (Formerly known as Ishik University), Erbil, Iraq, Email: yusra.baqal@ishik.edu.iq

Resource Accounting. that is modern, HRA possesses more importance as a powerful instrument for management decisions at internal human resource management in an organization. The perception towards the history of "labor and human resource management", HRA proposes a tool to develop management and measure human resources in an organization. If HRA has the capability to exhibit that improvement in HRM increases profits where integration of human capital applications by managers during their decisions at an increased level in an organization. (Flamholtz, Maria, \& Wei, 2002)

Disclosure of information through financial reporting externally at annual report to key stakeholders has improved basically for external users like bankers, lenders, stockholders and investors who are potential. The treatment of costs related to human resources under financial accounting decreases net income of the organization which was against investments which will furnish benefits in the future to the organization and assets are reported in the balance sheet as assets. Problems related to reporting human assets in the balance sheet where the measurement of human assets are subjective in nature though different models were developed. (Flamholtz, Maria, \& Wei, 2002)

The advancement of HRA has gone through five phases where the first stage started from 1960 to 1966. During the first stage, fundamental concepts of Human Resource Accounting were derived from various bodies related to theory. The second stage stated from 1967 to 1970 where research was made fundamentally by improving measurement models related to Human Resource Accounting. The third stage started from 1971 to 1977 where the interest towards Human Resource Accounting was rapid advancement. The fourth stage started from 1978 to 1980 where the interest towards Human Resource Accounting decreased among organizations as well as academia. The fifth stage started from 1981 to the present period where global interest towards theory and practice got renewed on Human Resource Accounting. (Flamholtz, Maria, \& Wei, 2002)

\section{LITERATURE REVIEW}

According to (Abeysekera \& Guthrie, 2004), with the new juncture in economic improvement that is defined by continuous innovation, the extension of technologies related to "digital and communication", issues related to the significance of intellectual capital, the applicability of organization's network 
forms, "relational capital", and organizational capital are emerged. Intangibles are being measured, managed, reported by many organizations, but the process of whole intellectual capital disclosure is at starting stage. Intellectual capital received notable focus among researchers and organizations which show interest towards significance of intangible disclosures.

According to (Cordon, 1998), researchers established evidence that the variation between the firm's "market value and book value" must be associated to the firm's intangibles.

Researchers showed evidence related to firm's market to books value is the indicator of significance of intellectual capital within the firm which has been enhancing during time passage. (Rylander, 2000)

The reporting of Intellectual Capital furnishes organizations with an opportunity to receive benefits of employing a meritorious marketing instrument, enhanced transparency towards capital markets, building trust among various stakeholders. (van der Meer \& Vosselman, 2000)

According to (Toms, 2002), information related to intellectual capital disclosure may assist to maintain and enhance intellectual capital's value provided that "intangible asset invention appear through enhanced reputation and reveal influences the external perception of reputation". The researcher identified revelations of intangible assets, brand creation and their reputation towards an organization.

Research made by (Corrado, Hulten, \& Sichel, 2005) revealed that ultimate problem related to development of measurement models that are reliable in measuring the value intangible assets. During the era of modern economy, various attempts were made in measuring intangible assets of an organization.

According to (Corrado, Hulten, \& Sichel, 2005), the adapted approach to measure intangible assets is according to the usage of data related to expenditure. As per this context, the estimation of intangible capital is made by "capitalizing expenditures" which generate long standing flow of revenues to the organization.

The standardization of advocated ingredients related to HRA was not made. The definitions of the ingredients related to HRA controls the measurement method which is the most suitable one where most of the researchers did not proceed towards its cost element, but approached by a model that is composite in nature related to organization's groups or individual members. (Mary M. K, 1977)

The question related to human resource accounting was "Do the employees really have a value over and beyond their compensation?" "Many people contend that they do, thus their exclusion results in not only an understatement of assets and a distortion of net

income, but also in incomplete and unreliable financial statements".(Mary M. K, 1977). Researcher tried to include behavioral reaction of employees to Human resource Accounting and revealed the outcomes as many were not interested to include their value in the financial statements.

\section{Research Objectives}

To observe the possibility of implementing human resource accounting practices towards educational institutions

To observe the impact of attitude towards human resource accounting on performance of undergraduate student's education

\section{Research Questions:}

What is possibility of implementing human resource accounting practices towards educational institutions?

What is the impact of attitude towards human resource accounting on performance of undergraduate student's education?

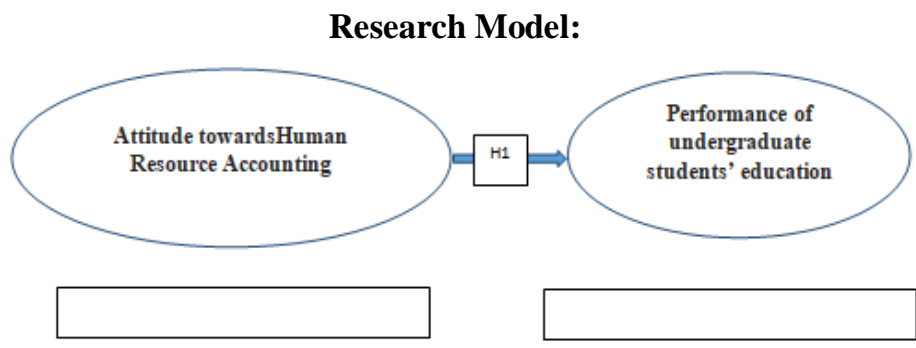

\section{Hypothesis:}

H0: There is no relation between attitude towards Human Resource Accounting and performance of undergraduate students' education.

H1: There is relation between attitude towards Human Resource Accounting and performance of undergraduate students' education

\section{Methodology:}

Researchers used convenience sampling technique and quantitative method for this study. Researchers adopted survey questionnaire from (Mary M. K, 1977) and (Sen, Jain, Jat, \& Saha, 2008). The total number of students in accounting department was 125 where 59 students responded to the questionnaire distributed. Researchers used Delphi technique where respondents are given chance to choose their responses in the first round randomly. All results of each item of the survey were shown to the respondents in the second round and requested to re-confirm their responses and provided freedom to change their responses. Researchers analyzed the data through EXCEL2016 and SPSS (23 V).

\section{Analysis:}

Demographic analysis

\begin{tabular}{|c|c|c|c|}
\hline \multicolumn{4}{|c|}{ Category of respondents } \\
\hline & & Frequency & Percent \\
\hline \multirow{3}{*}{ Valid } & 4th year & 38 & 64.4 \\
\hline & 3rd year & 21 & 35.6 \\
\hline & Total & 59 & 100 \\
\hline \multicolumn{4}{|c|}{ Gender } \\
\hline & & Frequency & Percent \\
\hline \multirow{3}{*}{ Valid } & Male & 30 & 50.8 \\
\hline & Female & 29 & 49.2 \\
\hline & Total & 59 & 100 \\
\hline \multicolumn{4}{|c|}{ Age } \\
\hline & & Frequency & Percent \\
\hline Valid & $16-20$ years & 3 & 5.1 \\
\hline
\end{tabular}




\begin{tabular}{|c|c|c|c|}
\hline \multirow{4}{*}{} & $20-25$ years & 56 & 94.9 \\
\cline { 2 - 4 } & Total & 59 & 100 \\
\hline \multicolumn{3}{|c|}{ Years of study at the University } \\
\hline \multirow{3}{*}{ Valid } & 2-4 years & Frequency & Percent \\
\cline { 2 - 4 } & 4-6years & 9 & 15.3 \\
\cline { 2 - 4 } & Total & 50 & 84.7 \\
\hline \multirow{3}{*}{} & \multicolumn{3}{c|}{} \\
\hline
\end{tabular}

Reliability Statistics

\begin{tabular}{|r|r|}
\hline $\begin{array}{c}\text { Cronbach's } \\
\text { Alpha }\end{array}$ & N of Items \\
\hline .779 & 19 \\
\hline
\end{tabular}

The reliability for the current study is reliable as Cronbach's Alpha value is .779 which is more than the standard i.e., .70 that is acceptable in social science studies.

\section{Reliability statistics}

Delphi Rounds for administering the survey

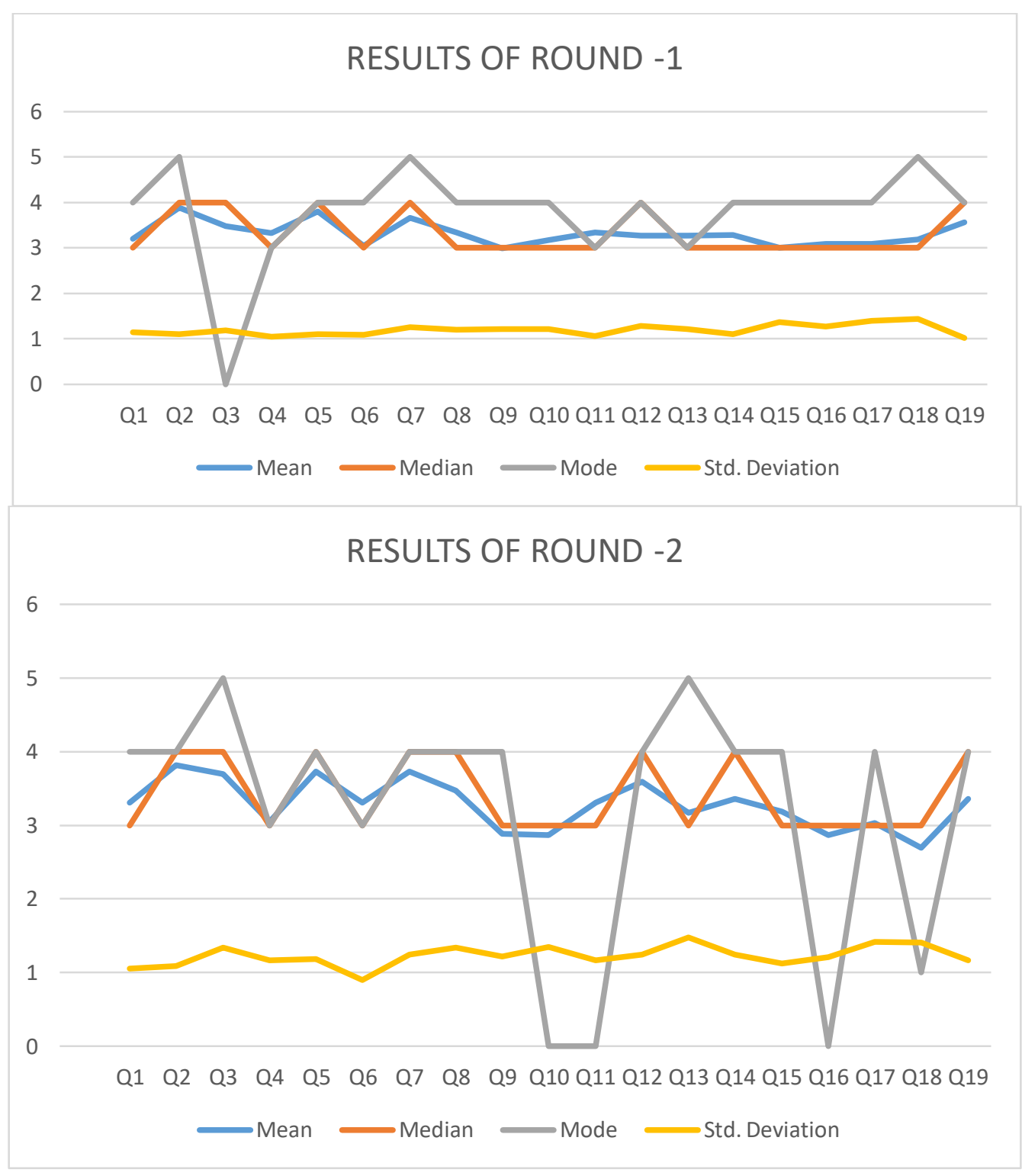

Researchers observed significant changes during second round of survey to the same respondents. Responses for Q3, Q10, Q11, Q16 and Q18 were completely different for both rounds and results were shared to the respondents. 
Impact of attitude towards Human Resource Accounting on performance of undergraduate students' education Evidence from private university students In Kurdistan Region - Iraq

Correlation Analysis

\begin{tabular}{|c|c|c|c|}
\hline \multicolumn{4}{|c|}{ Correlations } \\
\hline & & $\begin{array}{c}\text { Attitude towards } \\
\text { Human Resource } \\
\text { Accounting }\end{array}$ & $\begin{array}{l}\text { Performance of } \\
\text { undergraduate } \\
\text { students' education }\end{array}$ \\
\hline \multirow{3}{*}{$\begin{array}{l}\text { Attitude towards } \\
\text { Human Resource } \\
\text { Accounting }\end{array}$} & \begin{tabular}{|l} 
Pearson Correlation \\
\end{tabular} & 1 & $.398^{* *}$ \\
\hline & Sig. (2-tailed) & & .002 \\
\hline & $\mathrm{N}$ & 59 & 59 \\
\hline \multirow{3}{*}{$\begin{array}{l}\text { Performance of } \\
\text { undergraduate } \\
\text { students' education }\end{array}$} & Pearson Correlation & $398^{* *}$ & 1 \\
\hline & Sig. (2-tailed) & .002 & \\
\hline & $\mathrm{N}$ & 59 & 59 \\
\hline
\end{tabular}

The correlation analysis is to measure the relation between predictor variable and predicted variable. The value for Pearson Correlation between attitude towards Human Resource Accounting and performance of undergraduate students' education is $.398^{\text {** }}$ which indicates that there is positive and moderate relation between two variables.

\section{Regression Analysis}

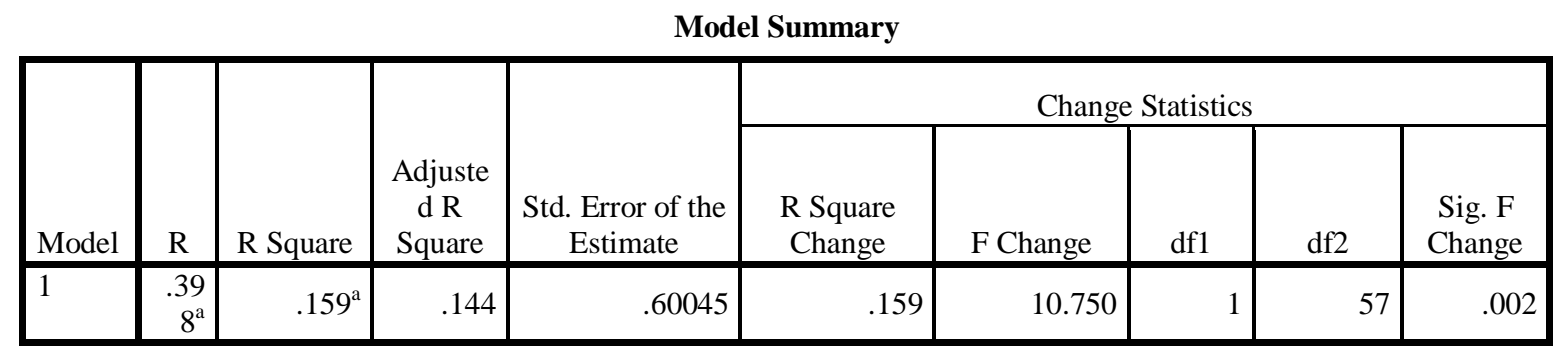

a. Predictors: (Constant), Attitude towards Human Resource Accounting

ANOVA ${ }^{a}$

\begin{tabular}{|ll|r|r|r|r|r|}
\hline Model & & Sum of Squares & df & Mean Square & F & Sig. \\
\hline 1 & Regression & 3.876 & 1 & 3.876 & 10.750 & $.002^{\text {b }}$ \\
& Residual & 20.551 & 57 & .361 & & \\
& Total & 24.427 & 58 & & & \\
& & & &
\end{tabular}

a. Dependent Variable: Performance of undergraduate students' education

b. Predictors: (Constant), Attitude towards Human Resource Accounting

Coefficients $^{\mathrm{a}}$

\begin{tabular}{|c|c|c|c|c|c|c|}
\hline \multirow[b]{2}{*}{ Model } & & \multicolumn{2}{|c|}{$\begin{array}{c}\text { Unstandardized } \\
\text { Coefficients } \\
\end{array}$} & \multirow{2}{*}{$\begin{array}{c}\text { Standardized } \\
\text { Coefficients }\end{array}$} & \multirow[b]{2}{*}{$\mathrm{t}$} & \multirow[b]{2}{*}{ Sig. } \\
\hline & & $\mathrm{B}$ & Std. Error & & & \\
\hline 1 & (Constant) & 1.855 & .427 & & 4.344 & .000 \\
\hline & Attitude towards & & & & & \\
\hline & $\begin{array}{l}\text { Human Resource } \\
\text { Accounting }\end{array}$ & .406 & .124 & .398 & 3.279 & .002 \\
\hline
\end{tabular}

a. Dependent Variable: Performance of undergraduate students' education

The above regression analysis depicts that there is a positive significant relationship with attitude towards Human Resource Accounting and performance of undergraduate students' education. $\mathrm{R}^{2}=0.159\left(\mathrm{R}=.159^{\mathrm{a}}\right.$, $\mathrm{P}<0.05)$ which means both variables were explained $15.9 \%$.

\section{CONCLUSION:}

Researchers would like to conclude that there is a positive significant relationship with attitude towards Human Resource Accounting and performance of undergraduate students' education. The null hypothesis got rejected in the study and alternative hypothesis got

Published By 
accepted. The research gap was identified by the researchers as literature was completely focused on reporting, measuring and evaluating the human values but overlooked the attitude part related to human resource accounting. Current research helps the educational institutions to understand the value of human resource accounting and implication of it to achieve high level of productivity among student community. Researchers observed the possibility of implementing human resource accounting practices towards educational institutions and based on the outcomes of the current research, educational institutions have moderate possibility to implement practices of HRA.

\section{LIMITATIONS:}

As this is pilot study, results may differ from present sample size to bigger sample size. This study is limited only to educational institutions where results may vary to other industries and geographical locations.

\section{ACKNOWLEDGEMENT:}

Authors would like to thank Tishk International University (Formerly known as Ishik University) for supporting current research.

\section{REFERENCES}

[1]. Abeysekera, I., \& Guthrie, J. (2004). The British Accounting Review, Vol. 36, No.3. "Human capital reporting in a developing nation, 251-268.

[2]. Cordon, B. (1998, January). Gaps In GAAP. Forbes, pp. 2628.

[3]. Corrado, C., Hulten, C., \& Sichel, D. (2005). Measuring Capital and Technology: An Expanded Framework'. 11-41.

[4]. Flamholtz, E. G., Maria, L. B., \& Wei, H. (2002). Human resource accounting: A historical perspective and future implications. Management Decisions, 947-954.

[5]. Mary M. K, .. F. (1977). BEHAVIORAL IMPLICATIONS OF HUMAN RESOURCE ACCOUNTING: A SURVEY OF POTENTIAL PROBLEMS. Behavioral Implications of HRA, 25-29.

[6]. Rylander, A. J. (2000). Towards improved information disclosure of intellectual capital. International Journal of Technology Management, Vol. 20 Nos 5/6/7/8, 715-741.

[7]. Sen, D., Jain, S., Jat, S., \& Saha, R. (2008). Human Resource Accounting Information: Its Impact on Internal DecisionMaking . The Journal of Accounting and Finance, 22(1), 2346.

[8]. Toms, J. (2002). Firm resources, quality signals and the determinants of corporate environmental reputation: some UK evidence. British Accounting Review, Vol. 34 No. 3, 257-282.

[9]. van der Meer, K. J., \& Vosselman, E. (2000). Management control of interfirm transactional relationships: the case of industrial renovation and maintenance. Accounting organizations and society, 25(1), 51-77. 